\title{
Cardiac surgery is evolving, but far from dead
}

\author{
Jessica Forcillo, MD, MSc, Eric L. Sarin, MD, and Vinod H. Thourani, MD
}

\author{
From Emory University Hospital Midtown, Atlanta, Ga. \\ Disclosures: Dr Thourani has had roles on the advisory boards of St Jude Medical, Edwards Lifesciences, Abbott \\ Medical, and Medtronic Corporation, and has conducted research for Medtronic, Edwards Lifesciences, \\ St Jude, Directflow, Abbott Medical, Boston Scientific, and LivaNova. All other authors have nothing to \\ disclose with regard to commercial support. \\ Received for publication Jan 31, 2016; accepted for publication Feb 2, 2016; available ahead of print March 5, \\ 2016. \\ Address for reprints: Vinod H. Thourani, MD, Emory University Hospital Midtown, 550 Peachtree St, NE, 6th Fl, \\ Medical Office Tower, Atlanta, GA 30308 (E-mail: vthoura@emory.edu). \\ J Thorac Cardiovasc Surg 2016;151:1470-1 \\ $0022-5223 / \$ 36.00$ \\ Copyright (c) 2016 by The American Association for Thoracic Surgery \\ http://dx.doi.org/10.1016/j.jtcvs.2016.02.005
}

Despite considerable advances during the past several decades, the global burden related to cardiovascular disease remains substantial. It is anticipated that by 2030, cardiovascular diseases will be among the 3 leading contributors to disability-adjusted life years (1 lost year of healthy life) and play a causal role in up to $65 \%$ of deaths worldwide. ${ }^{1}$ Despite this growing population of at-risk patients, there is considerable angst among cardiac surgeons about the role we will play in future treatments. In this issue, Whitson and Lima $^{2}$ assess the current landscape of cardiac surgery and anticipate a promising future.

Cardiac surgery as a specialty has been defined by relentless innovation in the pursuit of improving patient care. More recently, much of the innovation has been on catheter-based approaches allowing effective treatment of coronary artery disease, arrythmias, and valvular heart disease. It is reasonable to expect, as mentioned by Whitson and Lima, ${ }^{2}$ that these technologic advancements will create new opportunities (as seen with the growth of adult congenital surgery) and may lead to new challenges for multidisciplinary heart teams. Until now, we have found clinical equipoise in survival for high- and extreme-risk patients up to 5 years with the first generation of transcatheter aortic valve replacement devices. ${ }^{3-5}$ However, in exchange for decreased operative mortality, we accept less-than-perfect results by open surgical standards, including residual paravalvular leak and an increase in postoperative permanent pacemaker placement. As this technology is expanded into use among intermediate- and low-risk populations, it is of tremendous importance that we maintain our critical roles in not just the clinical trials themselves, but in the writing committees that analyze the data and create the new clinical guidelines for patient care. The way in which we practice cardiac surgery in the future will undoubtedly change, but the goal of providing the best possible outcome for a given pathology should not. As the push toward transcatheter

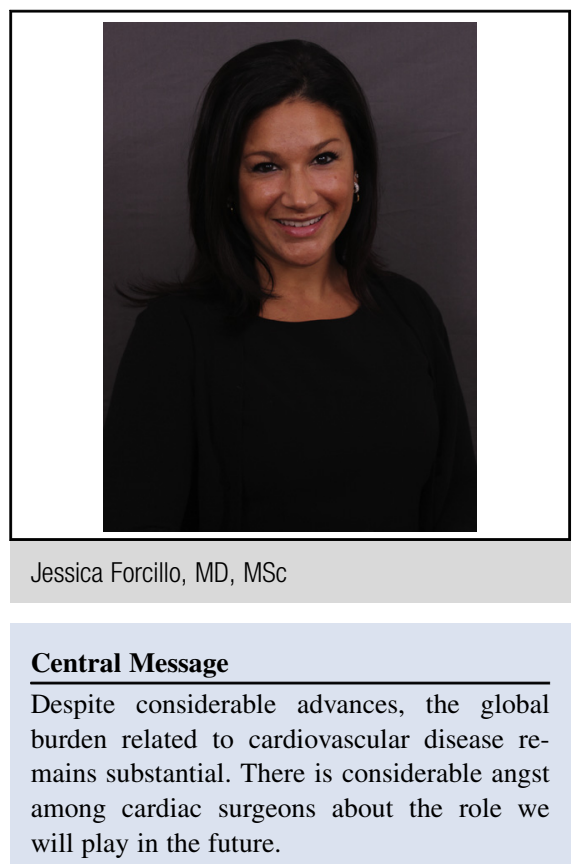

See Editorial page 1466.

aortic valve replacement implantation in lower-risk patients continues, we should remember the example of the Synergy Between Percutaneous Coronary Intervention and Cardiac Surgery (SYNTAX) trial ${ }^{6}$ and work to ideally match patients to therapy in the manner that is most beneficial to their health.

There will be an increasing demand for the skill sets associated with this radically evolving technology. We agree with Whitson and $\mathrm{Lima}^{2}$ that this needs to be addressed with increased exposure and education during residency training. It will also require a committment to constant improvement throughout the course of one's professional lifetime. Not just perfecting the techniques you know, but seeking out opportunites to add new techniques and innovations. Here again, we believe professional societies and our industry partners should play a major role in developing and maintaining a robust network of mentors and clinical sites for peer-to-peer training, as we have done here at Emory University (currently in our fifth year of a transcatheter structural heart and valve superfellowship).

As mentioned, new technologies have had considerable influence on the volume of cardiac surgical procedures being performed and the number of cardiac surgeons required in the future. Consequently, a significant number 
of recent graduates from cardiac surgery training programs across Canada, for example, remain unemployed, resulting in diminished interest from medical students and unfilled residency positions. Rates of coronary artery bypass graft surgery have been steadily declining since 2001 in favor of percutaneous angioplasty and this trend shows no sign of reversing. ${ }^{7}$ In contrast, the population is aging and rates of surgery other than coronary artery bypass graft, including interventions for heart failure, valvular disease, and aortic disease, are expected to increase. As such, it is expected that the overall demand for cardiac surgery will increase in the near future. Much like the US study from Grover and colleagues, ${ }^{8}$ an analysis of workforce dynamics by Feindel and colleagues in Canada $^{9}$ indicates that if present trends continue, a significant shortage of cardiac surgeons will develop by 2020 , even if coronary bypass volumes continue to decline by $1 \%$ each year.

Overall, this is an extremely exciting time for surgeons as long as we stay optimistic and open-minded. The practice of cardiac surgery will continue to evolve and change as it has since its inception. We are a fearless group with a long history of innovation and bravery. We should embrace these changes head-on. Cardiac surgery will never die, but as it continues to change, we must tirelessly work to guide its evolution in a manner consistent with our rich history and our brave forefathers.

\section{References}

1. Lozano R, Naghavi M, Foreman K, Lim S, Shibuya K, Aboyans V, et al. Global and regional mortality from 235 causes of death for 20 age groups in 1990 and 2010: a systematic analysis for the Global Burden of Disease Study 2010. Lancet. 2012;380:2095-128.

2. Whitson BA, Lima B. Surgery for acquired cardiac disease: an evolving paradigm with a promising future. J Thorac Cardiovasc Surg. 2016;151:1466-9.

3. Kodali SK, Williams MR, Smith CR, Svensson LG, Webb JG, Makkar RR, et al. Two-year outcomes after transcatheter or surgical aortic-valve replacement. N Engl J Med. 2012;366:1686-95.

4. Smith CR, Leon MB, Mack MJ, Miller DC, Moses JW, Svensson LG, et al. Transcatheter versus surgical aortic-valve replacement in high-risk patients. N Engl J Med. 2011;364:2187-98.

5. Mack MJ, Leon MB, Smith CR, Miller DC, Moses JW, Tuzcu EM, et al. 5-year outcomes of transcatheter aortic valve replacement or surgical aortic valve replacement for high surgical risk patients with aortic stenosis (PARTNER 1): a randomised controlled trial. Lancet. 2015;385:2477-84.

6. Mohr FW, Morice MC, Kappetein AP, Feldman T, Stahle E, Colombo A, et al Coronary artery bypass graft surgery versus percutaneous coronary intervention in patients with three-vessel disease and left main coronary disease: 5-year follow-up of the randomised, clinical SYNTAX trial. Lancet. 2013;381:629-38.

7. Hassan A, Newman A, Ko DT, Rinfret S, Hirsch G, Ghali WA, et al. Increasing rates of angioplasty versus bypass surgery in Canada, 1994-2005. Am Heart J. 2010;160:958-65.

8. Grover A, Gorman K, Dall TM, Jonas R, Lytle B, Shemin R, et al. Shortage of cardiothoracic surgeons is likely by 2020. Circulation. 2009;120:488-94.

9. Feindel CM, Ouzounian M, Latham TB, Hendry P, Langlois Y, Peniston C, et al The Canadian Society of Cardiac Surgeons perspective on the cardiac surgery workforce in Canada. Can J Cardiol. 2012;28:602-6. 